Research Article

Animal Genetics

\title{
Cytogenetic analysis of the genus Thoropa Cope, 1865 (Anura-Cycloramphidae) with evolutionary inferences based on repetitive sequences
}

\author{
Luiza Rieder Cholak ${ }^{1,2}$, Célio F. B. Haddad ${ }^{3}$ and Patrícia P. Parise-Maltempi ${ }^{1,2}$ (iD \\ ${ }^{1}$ Universidade Estadual Paulista (UNESP), Instituto de Biociências, Programa de Pós-graduação em \\ Biologia Celular e Molecular, Rio Claro, SP, Brazil. \\ ${ }^{2}$ Universidade Estadual Paulista (UNESP), Instituto de Biociências, Laboratório de Citogenética Animal, \\ Departamento de Biologia Geral e Aplicada, Rio Claro, SP, Brazil. \\ ${ }^{3}$ Universidade Estadual Paulista (UNESP), Instituto de Biociências, Laboratório de Herpetologia, \\ Departmento de Biodiversidade e Centro de Aquacultura (CAUNESP), Rio Claro, SP, Brazil.
}

\begin{abstract}
Cytogenetics can be a useful tool to assist in taxonomic problems by adding information to the widely used morphological and molecular approaches. These taxonomic problems are especially common in anurans, once they are very diverse, highly polymorphic, and present many cryptic species. The genus Thoropa Cope, 1865 is composed of six specialist species that reproduce in rocky outcrops and are distributed throughout the Atlantic Forest and Cerrado ecotones. Phylogenetic studies point to possible cryptic species within the T. miliaris group. To assist in the evolutionary and taxonomic understanding of this group, classical cytogenetic techniques were used to find possible molecular markers for the genus through rDNA5S, rDNA18S, and U2snDNA probes and analyze their chromosome distribution in the group of $T$. miliaris. Despite the well conserved karyotype under conventional staining and classical techniques, such as Ag-NOR, our C-banding results showed differences in the centromeric heterochromatin concentration between two populations of $T$. miliaris. Furthermore, some differences among the populations and species were found for rDNA5S and U2snDNA. This study contributes to a better understanding of the evolutionary relationships within the genus; however, the use of different probe sequences, such as satDNA, is essential for a more robust cytogenetic analysis.
\end{abstract}

Keywords: FISH, rDNA, snDNA, cytogenetic evolution, chromosomes.

Received: October 30, 2019; Accepted: June 06, 2020.

\section{Introduction}

The genus Thoropa was described by Cope in 1865, and Thoropa miliaris was the first species to be named. Since then, five more species have been described and are currently divided into two groups: Thoropa petropolitana, with T. petropolitana (Wandolleck, 1907) and T. lutzi Cochran, 1938 and Thoropa miliaris, composed of T. miliaris (Spix, 1824), T. taophora (Miranda-Ribeiro, 1923), T. megatympanum Caramaschi and Sazima, 1984, and T. saxatilis Cocroft and Heyer, 1988 (Feio, 2002).

Of the six species that make up the genus, all endemic to Brazil, the two belonging to the T. petropolitana group are very rare and have not been seen in the wild for almost five decades (Feio, 2002). Regarding the four T. miliaris group

Send correspondence to Patricia Pasquali Parise-Maltempi. Instituto de Biociências, Departamento de Biologia Geral e Aplicada. Laboratório de Citogenética Animal, Avenida 24A, 1515, 13506-900. Rio Claro, SP, Brazil. E-mail: patricia.parise@unesp.br. species, $T$. miliaris is the most widely distributed, occurring from southern Bahia to the extreme south of São Paulo state, found in humid rocky outcrops at sea level, to altitudes close to $2000 \mathrm{~m}$ (Giaretta and Facure, 2004; Feio et al., 2006; Fitzpatrick et al., 2009). T. megatympanum is endemic to the Espinhaço mountain range in the Brazilian states of Minas Gerais and Bahia, and inhabits rupestrian fields (Caramaschi and Sazima, 1983; Feio et al., 2002; Eterovick and Sazima, 2004).

The distribution of $T$. saxatilis is restricted to the southern region of Brazil, occurring from Santa Catarina to Rio Grande do Sul states and found on the slopes of Serra Geral mountain range. Finally, T. taophora, popularly known as stone frog, sheep frog, or goat frog (Verdade et al., 2009; Brasileiro et al., 2010), inhabits outcrop rocks from the beaches to within the Atlantic Forest on the coastal regions of Serra do Mar mountain range, São Paulo state, similarly to T. miliaris (Feio et al., 2002; Brasileiro et al., 2010). In addition, $T$. taophora shows high tolerance to salinity and is commonly found in tidal regions, a niche rarely occupied 
by amphibians, due to their permeable and non-keratinized skin, which is sensitive to salty water (Abe and Bicudo, 1991; Fitzpatrick et al., 2009).

From a phylogenetic point of view, some studies suggest the existence of cryptic species in the genus, particularly within T. miliaris and T. taophora (Fitzpatrick et al., 2009; Sabbag et al., 2018), and T. miliaris is actually believed to be a species complex (Feio et al., 2006; Sabbag et al., 2018). Sabbag et al. (2018), analyzing nuclear and mitochondrial genes for species of the Thoropa miliaris group, found five distinct clades for T. miliaris that appear to be evolving independently, in addition to a paraphyly of $T$. miliaris related to $T$. taophora. The other species in the group appear to be monophyletic.

Morphological changes often do not follow speciation processes (Bickford et al., 2007). In addition, polymorphisms among populations are expected, which requires the use other tools to differentiate species. The biodiversity of anurans must be investigated to allow the development of management plans to ensure the preservation of species, especially the ones of restricted distribution showing evidence of population decline and / or ecological specializations. In addition, a thorough cytogenetic knowledge on groups will set the ground for a better comprehension of chromosomal evolution processes and gene organization.

\section{Material and Methods}

Samples of the four species belonging to the T. miliaris group were analyzed: 12 individuals of $T$. miliaris from
Paraty, Rio de Janeiro state (RJ) and seven from Santa Teresa, Espírito Santo state (ES); five T. taophora individuals from Ubatuba, São Paulo state (SP) and twelve from São Sebastião, SP; four T. megatympanum individuals from Santana do Riacho, Minas Gerais state (MG); and five T. saxatilis individuals from Timbé do Sul, Santa Catarina state (SC). All fixed specimens were deposited in the Célio F. B. Haddad Amphibian Collection (CFBH), at the Biodiversity Department, Biosciences Institute, UNESP, Rio Claro, SP, Brazil (Table 1). The collection procedures were approved by the Chico Mendes Institute of Biodiversity Conservation (ICMBio) (authorization numbers 55031-2 and 50280-2).

\section{Cytogenetic preparations and banding techniques}

Cell suspensions were obtained from the liver, spleen, bone marrow, intestine, and testes following a combination of the procedures described by Schmid (1978) and Baldissera Jr. et al. (1993) after treatment with 1\% colchicine for 4 hours. Conventional 5\% Giemsa staining was used for ploidy determination and chromosome morphological characterization. C-banding techniques were performed according to Sumner (1972), with change in barium exposure time and Ag-NOR according to Howell and Black (1980). Five to twenty metaphases were analyzed per individual. All procedures were approved by the Animal Use Ethics Committee (permission 1554/2016), Biosciences Institute, UNESP, Rio Claro, SP, Brazil.

Table 1 - Species used in the study, with their respective populations, geographic coordinates of collection places, number of individuals of each gender, registration numbers, and gender $(\mathrm{M}=$ male; $\mathrm{F}=$ female $)$.

\begin{tabular}{|c|c|c|c|c|c|}
\hline Species & Population & Geographic coordinates & Number of individuals & Registration number & Sex \\
\hline T. miliaris & Paraty/RJ & $\begin{array}{l}23^{\circ} 13^{\prime} 12.08^{\prime \prime} \mathrm{S} \\
44^{\circ} 43^{\prime} 13.54^{\prime \prime} \mathrm{W}\end{array}$ & 4 & CFBH42175; 42177-78; 42205 & $\mathrm{~F}$ \\
\hline T. miliaris & Paraty/RJ & $\begin{array}{l}23^{\circ} 13^{\prime} 12.08^{\prime \prime} \mathrm{S} \\
44^{\circ} 43^{\prime} 13.54^{\prime \prime} \mathrm{W}\end{array}$ & 8 & $\begin{array}{c}\text { CFBH42174; 42176; 42179-82; } \\
42202-03\end{array}$ & M \\
\hline T. miliaris & Santa Teresa/ES & $\begin{array}{l}19^{\circ} 56^{\prime} 13.64 " \mathrm{~s} ; \\
40^{\circ} 35^{\prime} 53.06^{\prime \prime} \mathrm{W}\end{array}$ & 1 & CFBH43625 & $\mathrm{F}$ \\
\hline T. miliaris & Santa Teresa/ES & $\begin{array}{l}19^{\circ} 56^{\prime} 13.64 " \mathrm{~S} ; \\
40^{\circ} 35^{\prime} 53.06^{\prime \prime} \mathrm{W}\end{array}$ & 6 & $\begin{array}{c}\text { CFBH43600-01; 43610; 43613; } \\
43619 ; 43621\end{array}$ & M \\
\hline T. taophora & Ubatuba/SP & $\begin{array}{l}23^{\circ} 13^{\prime} 54.46^{\prime \prime} \mathrm{S} ; \\
44^{\circ} 43^{\prime} 02.04^{\prime \prime} \mathrm{W}\end{array}$ & 2 & CFBH42209-10 & $\mathrm{F}$ \\
\hline T. taophora & Ubatuba/SP & $\begin{array}{l}23^{\circ} 13^{\prime} 54.46^{\prime \prime} \mathrm{S} \\
44^{\circ} 43^{\prime} 02.04^{\prime \prime} \mathrm{W}\end{array}$ & 3 & CFBH42207; 42211-12 & M \\
\hline T. taophora & São Sebastião/SP & $\begin{array}{l}23^{\circ} 46^{\prime} 46.63 ” \mathrm{~S} \\
45^{\circ} 37^{\prime} 08.96^{\prime \prime} \mathrm{W}\end{array}$ & 2 & CFBH43579; 43582 & $\mathrm{~F}$ \\
\hline T. taophora & São Sebastião/SP & $\begin{array}{l}23^{\circ} 46^{\prime} 46.63^{\prime \prime} \mathrm{S} ; \\
45^{\circ} 37^{\prime} 08.96^{\prime \prime} \mathrm{W}\end{array}$ & 10 & $\begin{array}{l}\text { CFBH43572-74; 43576-78; } \\
\quad 43580-81 ; 43587-88\end{array}$ & M \\
\hline T. megatympanum & $\begin{array}{l}\text { Santana do } \\
\text { Riacho/MG }\end{array}$ & $\begin{array}{l}19^{\circ} 20^{\prime} 53.4^{\prime \prime} \mathrm{S} \\
43^{\circ} 59^{\prime} 83.2^{\prime \prime} \mathrm{W}\end{array}$ & 4 & CFBH43594-97 & M \\
\hline T. saxatilis & Timbé do Sul/SC & $\begin{array}{l}28^{\circ} 49^{\prime} 45.38^{\prime \prime} \mathrm{S} \\
49^{\circ} 54^{\prime} 57.444^{\prime \prime O}\end{array}$ & 4 & CFBH44454-57 & $\mathrm{F}$ \\
\hline T. saxatilis & Timbé do Sul/SC & $\begin{array}{l}28^{\circ} 49^{\prime} 45.38^{\prime \prime} \mathrm{S} \\
49^{\circ} 54^{\prime} 57.44^{\prime \prime} \mathrm{O}\end{array}$ & 1 & CFBH44458 & M \\
\hline
\end{tabular}




\section{Base-specific fluorochrome labeling and in situ hybridization}

FISH labeling was performed for rDNA18S, rDNA5S, and U2 snDNA probes, the first two from amphibian and the third one from fish, according to Pinkel et al. (1986), with modifications according to Cabral de Mello (2010). Telomeric sequence (TTAGGG) FISH followed the protocol provided in the PNA FISH Telomere / FITC kit (Dako Cytomation, Denmark). Probes were amplified from the extracted DNA of the studied species by polymerase chain reaction (PCR) using the primers shown in Table 2 and labeled by PCR or nick-translation using biotin-14-dATP (Invitrogen) or digoxigenin-11-dUTP (Roche, Mannheim, Germany), according to Pinkel et al. (1986). Chromomycin A3 (CMA3) technique was performed according Christian et al. (1998).

\section{Karyotypic analysis}

Corel PHOTO-PAINT X8 was used for the construction of the karyotypes. Chromosomic morphology was visually determined, and the classification was performed according to Guerra (1986). The labeled chromosomes were analyzed using Olympus BX51 photomicroscope (Tokyo, Japan) at 1600x and 2000X magnifications. The best preparations were photographed using a DP71 camera attached to a microcomputer.

\section{Results}

All four species had $2 \mathrm{n}=26$ and $\mathrm{FN}=52$ showing a conserved karyotype for the genus, both for ploidy and morphology. All the species / populations showed five pairs of large chromosomes and eight smaller pairs, and all chromosomes were metacentric or submetacentric, with a secondary constriction on the long arm of pair 6 (Figure 1). Regarding the Ag-NOR (Figure 1 - white squares) and CMA3 techniques (Figure 1 - black squares). The results were consistent between the two techniques and all species / populations were marked on the secondary constriction pair.

Centromeres and some telomeres markings in chromosomes were observed for all species / populations in the C-banding technique, without interstitial markings (Figure 2). The telomeric probe FISH results for T. miliaris from Paraty and Santa Teresa, and for T. Taophora from Ubatuba showed no interstitial marking (Figure S1).

The FISH technique using a rDNA $18 \mathrm{~S}$ probe showed marking consistent with those obtained by silver nitrate impregnation, confirming the location of the NOR in the secondary constriction of pair 6 (Figure 3). The same region was also evidenced by the CMA3 technique (Figure 3, black squares).

Regarding the U2 snDNA, some signal variations were observed among the analyzed species. In T. miliaris from Paraty, signals appeared in the telomeric region of the short arms in pair 6 and in the centromeric region of pair 7. In $T$. miliaris from Santa Teresa, signals were found in these same chromosome pairs and regions; however, the signals of pair 6 appeared in the long arms. For T. taophora chromosomes (Ubatuba and São Sebastião, SP), the markings were detected in the telomeric and pericentromeric regions of the pairs 6 and 7, respectively. Similarly, the telomeric region of the long arm of pair 6 in T. megatympanum was marked, and, in T. saxatilis, only the centromeric region of pair 7 (Figure 4).

In situ hybridization using the $5 \mathrm{~S}$ rDNA as probe showed strong markings in the pericentromeric region of the pair 1 for both T. miliaris populations. For T. taophora, pericentromeric markings were detected in pairs 1 and 6 of the Ubatuba population, and the same markings in these pairs of the population of São Sebastião, as well as a telomeric signal in pair 5, the latter present only in this population. In T. saxatilis, markings were observed in the pericentromeric region of the pair 1 and telomeric region of pair 5 (Figure 5).

\section{Discussion}

Overall, the results point to a conserved karyotype in the group, since the species and different populations presented the same chromosome number $(2 n=26)$, fundamental number $(\mathrm{FN}=52)$ and chromosome morphology, including the presence of a secondary constriction in the long arm of pair 6 (Figure 1). In addition, heterochromatic bands were identified only in telomeres and centromeres (Figure 2), an expected pattern for anurans (Schmid et al., 2014).

Ag-NOR, CMA3 (Figure 1) and rDNA18S (Figure 3) markings confirmed the location of NOR in the secondary constriction of the pair 6 for all the species / populations analyzed. This was also expected, since the presence of only one NOR-containing site is a general characteristic for anurans, considering the ancestral condition of the group (King, 1990). In addition, the heterochromatin concentration differences among $T$. miliaris populations suggest an accumulation of centromeric chromatin in the Santa Teresa, ES population This suggests a possible speciation process (Figure 2B), supported by the recovery of five distinct clades in T. miliaris, which may be evolving independently (Sabbag et al., 2018).

Table 2 - Probes and primers sequence used in the present work. rDNA $18 \mathrm{~S}$ and $5 \mathrm{~S}$ it were designed in this present paper and U2snDNA is from Bueno $e t$ al. (2013)

\begin{tabular}{lccc}
\hline Probe & Forward sequence & Reverse sequence & Annealing ${ }^{\circ} \mathrm{C}$ \\
\hline rDNA18S & AATTCCAGCTCCAATAGCGT & CCGCGGGCCTGATTTGAA & $60{ }^{\circ} \mathrm{C}$ \\
rDNA5S & TACGGCCACACCACCCTGAA & CAGGCGGTCTCCCATCCAGGT & $59{ }^{\circ} \mathrm{C}$ \\
U2snDNA & ATCGCTTCTCGGCCTTAT & TCCCGGCGGTACTGCAAT & $55^{\circ} \mathrm{C}$ \\
\hline
\end{tabular}


A

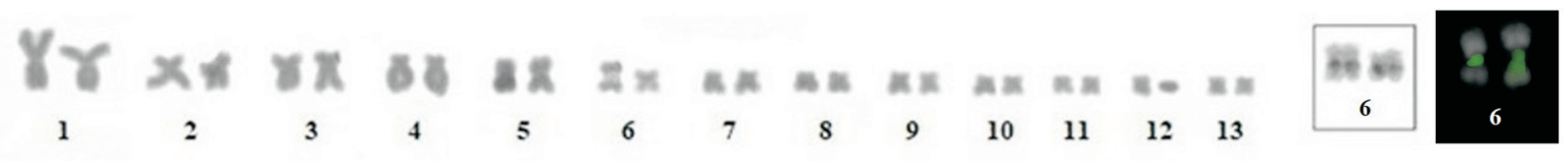

B
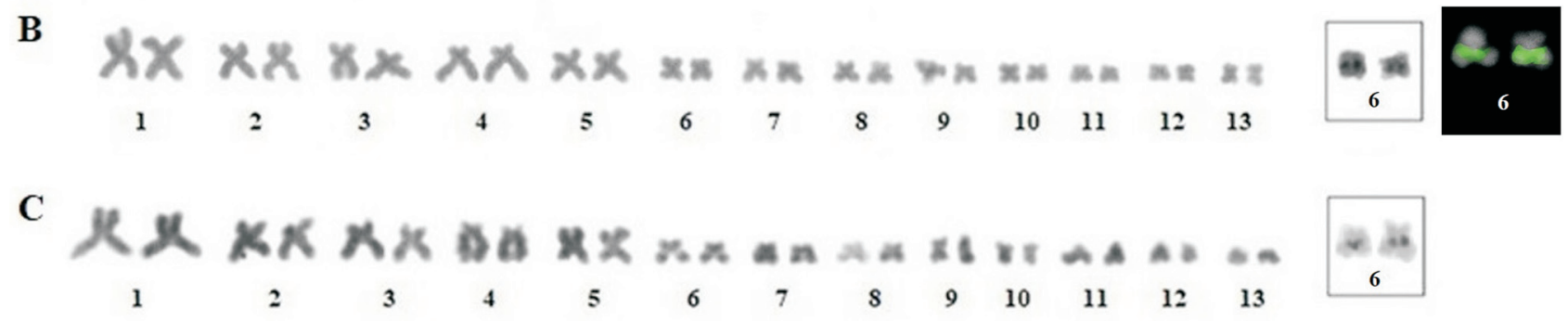

D
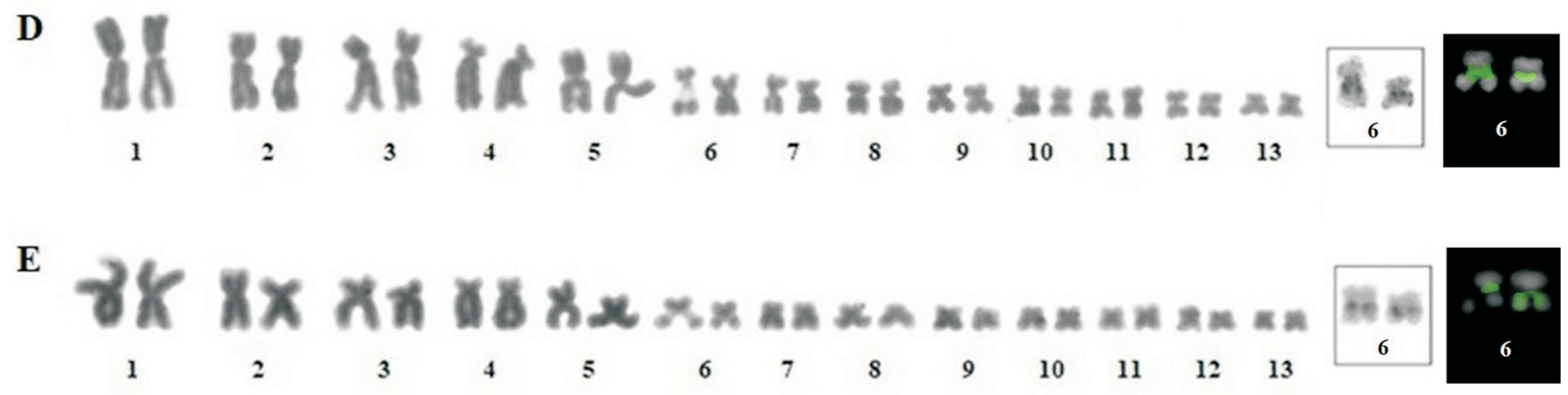

$\mathbf{F}$

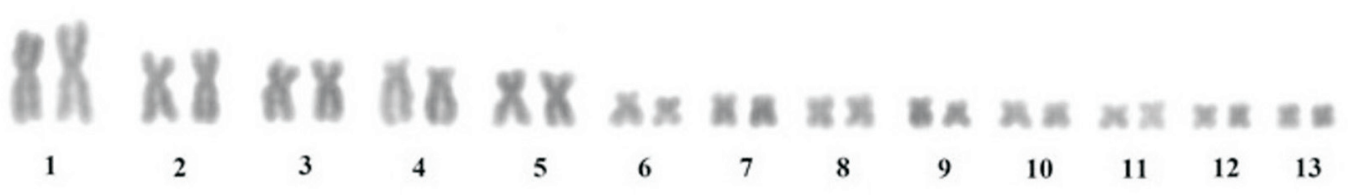

$10.0 \mu \mathrm{m}$

Figure 1 - Karyotypes of the four species of the genus Thoropa: (A) T. miliaris, population of Paraty, RJ; (B) T. miliaris, population of Santa Teresa, ES; (C) T. taophora, population of Ubatuba, SP; (D) T. taophora, population of São Sebastião, SP; (E) T. megatympanum, Santana do Riacho, MG; (F) T. saxatilis, Timbé do Sul, SC. Highlighted in the white square, the NORs in pair 6, in the black square is the CMA3 marking also in pair 6.

The variations observed in U2 snDNA and rDNA5S probes, in turn, allow us to infer some hypotheses for the karyotypic evolution within the group. According to Sabbag et al. (2018), T. saxatilis would be the oldest species and the first one to diverge, followed by T. megatympanum and the T. miliaris $+T$. taophora species complex. With specific regard to U2, T. saxatilis has a pericentromeric marking in pair 7, similarly to T. miliaris and T. taophora; however, unlike these, it does not show marking in pair 6 (Figure 4). Thoropa megatympanum (the second to differ after T. saxatilis) on the other hand, presents only the marking in the telomeric region of the long arms of the pair 6, as well as in T. miliaris, population of Paraty. The marking in pair 6 is repeated for all the species and populations, except for $T$. saxatilis; however, in the T. miliaris population of Santa Teresa, ES, and in the two populations of T. taophora (Ubatuba and São Sebastião, $\mathrm{SP}$ ), the marking occurs at the end (telomeric region) of the short arm of pair 6, indicating a possible inversion in the population of Paraty, RJ. Despite having highly conserved sequences in eukaryotes, snDNA U2 vary in number and organization in the genomes of different species (Úbeda-Manzanaro et al., 2010; Garcia-Souto et al., 2015).

Concerning the 5S rDNA, even more variation was observed (Figure 5), since differences were found among species and populations (for T. taophora), not only in the position of the marking, but also in the distribution of these sequences among chromosomes. According to Sabbag et al. (2018), T. saxatilis would have been the first of the group to diverge; however, we cannot consider its karyotypic condition as ancestor. Therefore, it is not possible, with these results, to predict whether the copies of this sequence were acquired in par 6 by $T$. taophora during the differentiation process, or if it was lost in T. saxatilis. Both populations of $T$. miliaris maintained markings only in the pair 1, a common feature among species that have $5 \mathrm{~S}$ rDNA in only one locus 


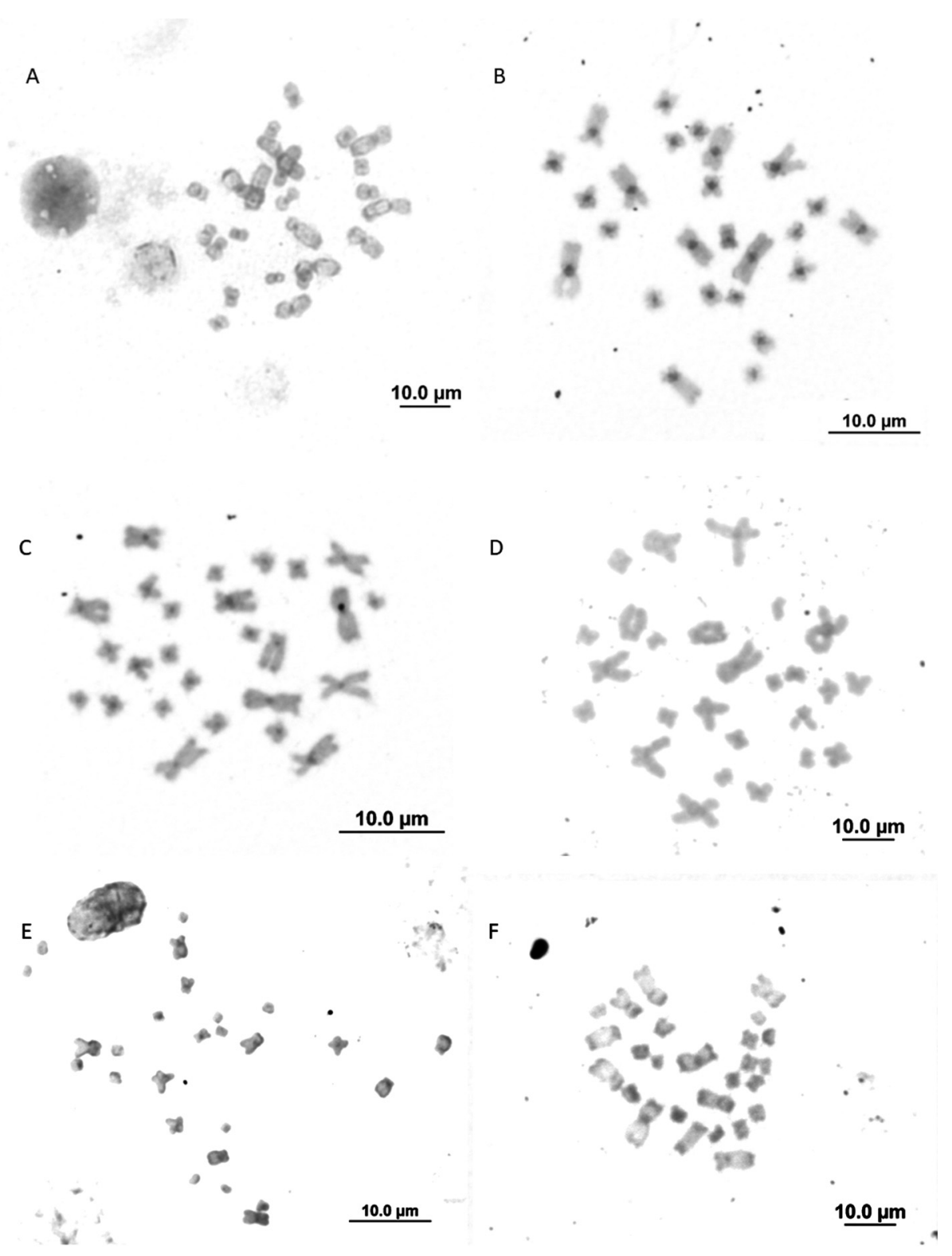

Figure 2 - C-banding: T. miliaris (A and B) Paraty, RJ and Santa Teresa, ES, respectively; (C and D) T. taophora Ubatuba, SP and São Sebastião, SP, respectively; (E) T. megatympanum, Santana do Riacho, MG; (F) T. saxatilis, Timbé do Sul, SC.

(Garcia et al., 2017), having both lost these sequences on chromosomes 5 and 6.

The 5S rDNA consists of approximately $120 \mathrm{bp}$ tandem repeat sequences, highly conserved and flanked by non-transcribed spacer DNA, the latter quite variable in size and sequence identity (Wasko et al., 2001; Eickbush and Eickbush, 2007; Garcia et al., 2017). The 5S rDNA is species-specific and has been used as a good comparative parameter for evolutionary studies at the chromosomal level (Wasko et al., 2001). Polymorphisms involving this sequence are characterized in animal and plant groups (Wasko et al., 2001), including anurans (Vittorazzi et al., 2011), and may be a good marker for distinguishing closely related species, subspecies, and hybrids (Pendas et al., 1995; Rodrigues et al., 2012). Studies with fish (Martins et al., 2002), oysters
(Cross et al., 2003), and anurans (Vittorazzi et al., 2011) show that $5 \mathrm{~S}$ has two smaller units different from each other, which usually appear on other chromosomes than the one where the large unit is located. As sequence homogenization and maintenance is often due to uneven crossing-over or gene conversion (Martins and Galetti, 1999), which occur more frequently in telomeric regions, subcentromeric markings are commonly found in fish (Eirín-López et al., 2012). The number of clusters in which 5S appears organized varies among different groups of plants and animals, and, in fish, $5 \mathrm{~S}$ is generally clustered into just one chromosomal pair and in this group probably represents the ancestral condition (Martins and Galetti, 1999). Regarding amphibians, urodeles show no intraspecific variation either in number or location of rDNA 5S (Barsacchi-Pilone et al., 1977; Vitelli et 


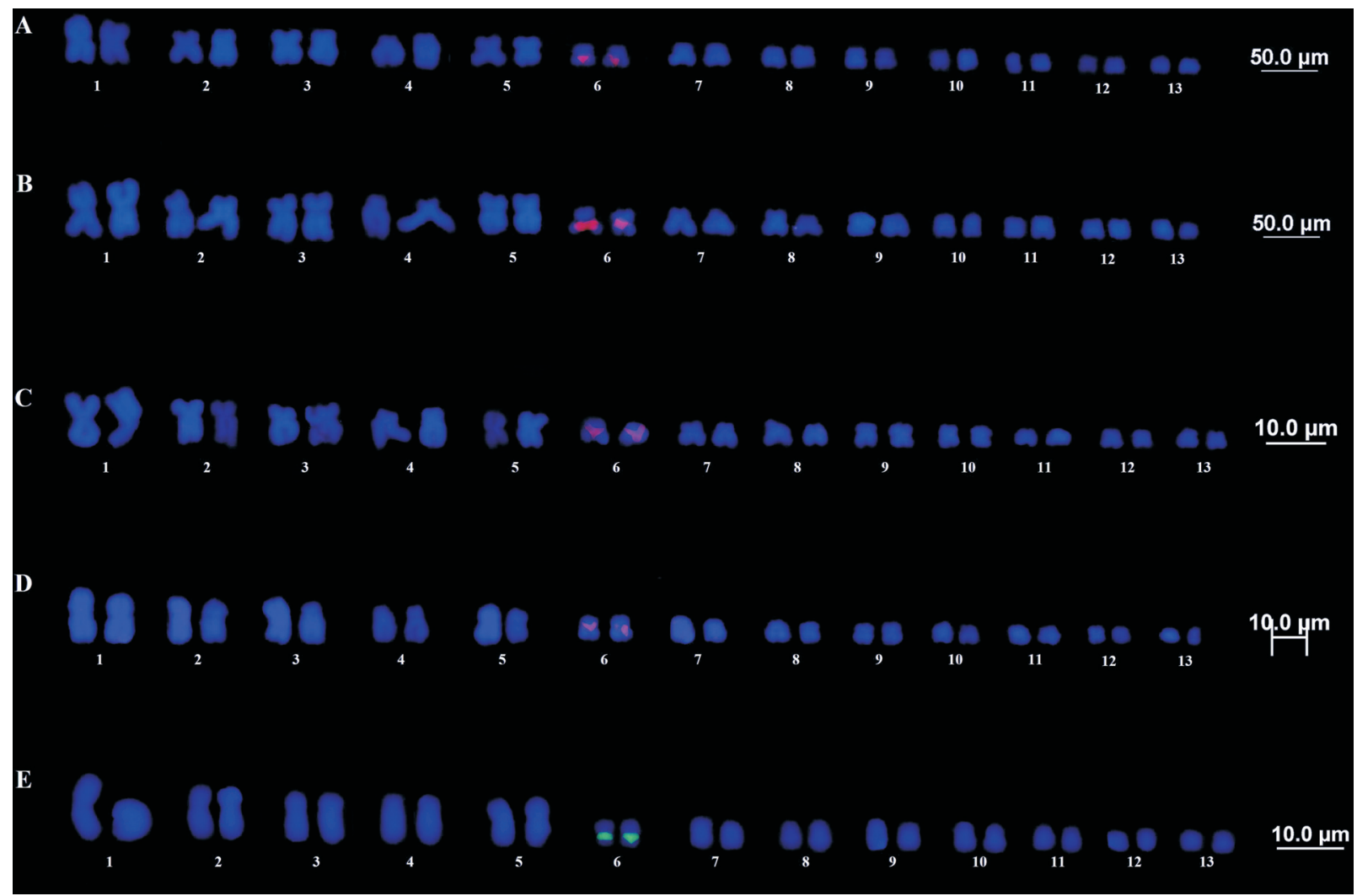

Figure 3 - FISH rDNA 18S. (A and B) T. miliaris, Paraty, RJ and Santa Teresa, ES, respectively. (C and D) T. taophora, Ubatuba, SP and São Sebastião, SP, respectively. (E) T. saxatilis, Timbé do Sul, SC.

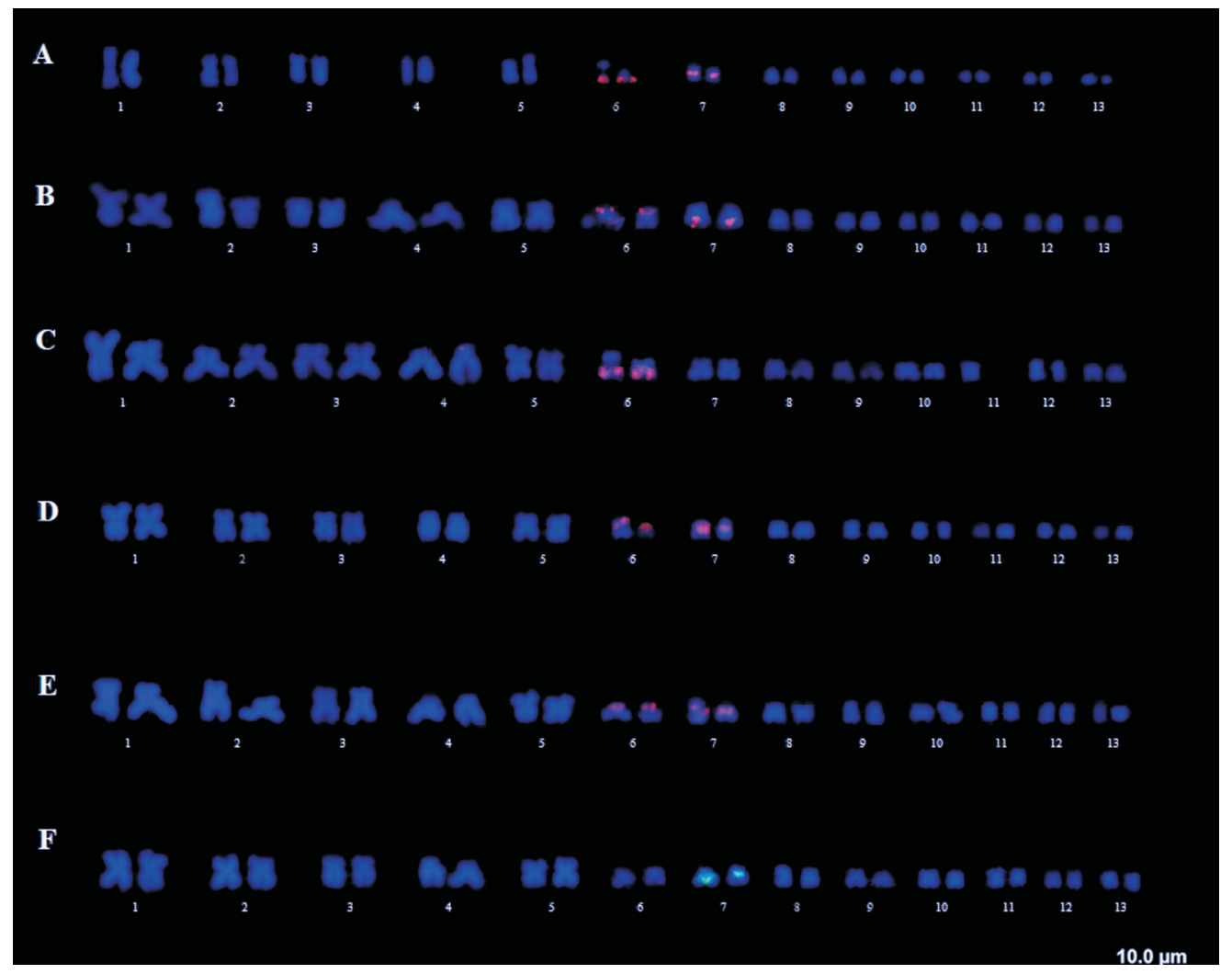

Figure 4 - snDNA U2 FISH. (A and B) T. miliaris, population of Paraty, RJ and Santa Teresa, ES, respectively; (C) T. megatympanum, Santana do Riacho, MG. (D and E) T. taophora, population of Ubatuba, SP and São Sebastião, SP, respectively. (F) T. saxatilis, Timbé do Sul, SC. 


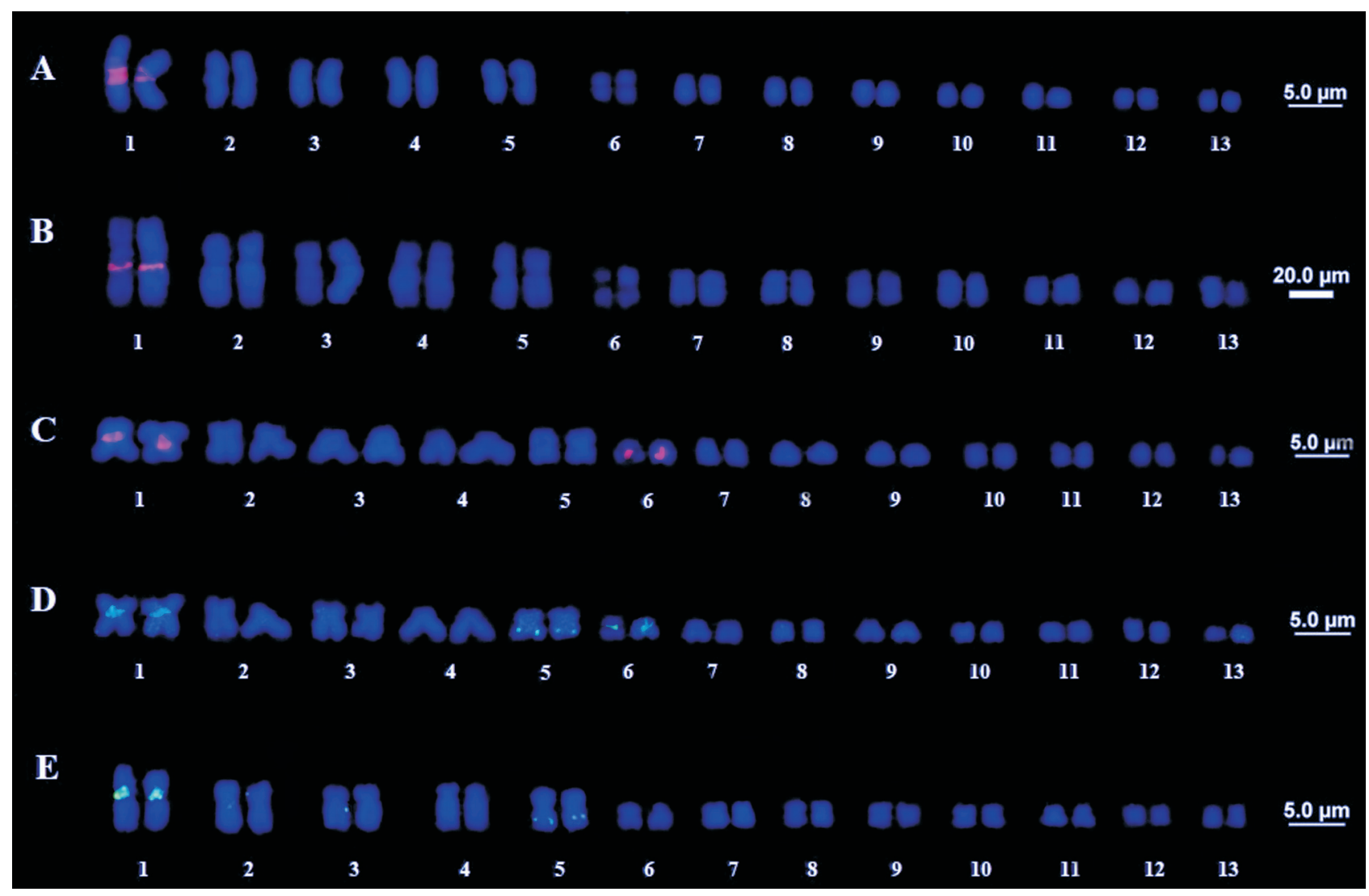

Figure 5 - 5S rDNA FISH. (A and B) T. miliaris, Paraty, RJ and Santa Teresa, ES, respectively. (C and D) T. taophora, Ubatuba, SP and São Sebastião, SP, respectively. (E) T. saxatilis, Timbé do Sul, SC.

al., 1982; De Lucchini et al., 1993), although some studies have reported interspecific variation even among closely related species (De Lucchini et al., 1993). When 5S appears in more than one chromosomal locus, it can represent the different units (larger and smaller) of the gene. In addition, there may be size and / or signal polymorphisms in the clusters between homologs and, possibly, because of the low copy quantity, the signal is weak (Martins and Galetti, 1999). In fact, in fish (Martins and Galetti, 2001) and amphibians (Harper et al., 1983; De Lucchini et al., 1993; Vittorazzi et al., 2011; Rodrigues et al., 2012), unlike the mammalian pattern, 5S may be distributed among several chromosomes. This characteristic may reflect the absence of non-homologous sequence exchange between different $5 \mathrm{~S}$ bearing chromosomes, and suggest that these sequences evolve independently (Martins et al., 2002).

Polymorphisms among species / populations were found for snDNA U2 and rDNA 5S sequences. Interestingly, T. miliaris populations showed polymorphism with respect to the location of snDNA U2, but not to the location of $5 \mathrm{~S}$. According to Sabbag et al. (2018), phylogenetic analyses show that $T$. miliaris is probably a species complex, since five clades were recovered for the species, which seems to be evolving independently. Conversely, T. taophora populations showed different FISH markings for the rDNA 5S sequence, but had the same markings for snDNA U2; however, it is not possible to make phylogenetic inferences even based on Sabbag et al. (2018), as 5S is expected to be polymorphic. These findings provide relevant information to existing molecular and morphological data; however, further cytogenetic approaches, including cytogenomic research, are still needed to better understand these differences and how they may reflect in the group taxonomy.

\section{Acknowledgments}

The authors would like to thank the research funding agency Coordenação de Aperfeiçoamento de Pessoal de Nível Superior - Brasil (CAPES) - Finance Code 001. We also thank Ariadne Fares Sabbag and João Luiz Gasparini for their contributions in the field collections. CFBH is grateful to CNPq, for a research fellowship (306623/2018-8), and FAPESP, for financial support (\#2013/50741-7).

\section{Conflict of Interest}

The authors declare that there is no conflict of interest that could be perceived as prejudicial to the impartiality of the reported research. 


\section{Authors Contributions}

LRC and PPPM conceived the study; LRC collected specimens, conducted the experiments and wrote the manuscript; LRC and PPPM analyzed the data; CFBH helped to identify the specimens; PPPM and $\mathrm{CFBH}$ provided financial support; All authors read and approved the final version.

\section{References}

Abe AS and Bicudo JEPW (1991) Adaptations to salinity and osmoregulation in the frog Thoropa miliaris (Amphibia, Leptodactylidae). Zool Anz 5-6:313-318.

Baldissera FA, Deoliveira PL and Kasahara S (1993) Cytogenetics of 4 Brazilian Hyla species (Amphibia-Anura) and description of a case with a supernumerary chromosome. Rev Bras Genet 2:335-345.

Barsacchi-Pilone G, Nardi I, Andronico F, Batistoni R and Durante M (1977) Chromosomal location of the ribosomal RNA genes in Triturus vulgaris meridionalis (Amphibia, Urodela). Chromosoma 63:127-134.

Brasileiro CA, Martins M and Sazima I (2010) Feeding ecology of Thoropa taophora (Anura: Cycloramphidae) on a rocky seashore in southeastern Brazil. South Am J Herpetol 5:181-189.

Bruschi DP, Rivera M, Lima AP, Zúñiga AB and Recco-Pimentel SM (2014a) Interstitial telomeric sequences (ITS) and major rDNA mapping reveal insights into the karyotypical evolution of Neotropical leaf frogs species (Phyllomedusa, Hylidae, Anura). Mol Cytogenet 7:22.

Bruschi DP, Rivera M, Lima AP, Zúñiga AB and Recco-Pimentel SM (2014b) Molecular and morphological evidence reveals a new species in the Phyllomedusa hypochondrialis group (Hylidae, Phyllomedusinae) from the Atlantic Forest of the highlands of southern Brazil. PloS One 9:e105608.

Bueno D, Palacios-Gimenez OM and Cabral De Mello DC (2013) Chromosomal mapping of repetitive DNAs in the grasshopper Abracris flavolineata reveal possible ancestry of the B chromosome and H3 histone spreading. PLoS One 8:e66532.

Cabral-de-Mello DC, Moura RC and Martins C (2010) Chromosomal mapping of repetitive DNAs in the beetle Dichotomius geminatus provides the first evidence for an association of $5 \mathrm{~S}$ rRNA and histone $\mathrm{H} 3$ genes in insects, and repetitive DNA similarity between the B chromosome and A complement. Heredity (Edinb) 104:393.

Caramaschi U and Sazima I (1983) Uma nova espécie de Thoropa da Serra do Cipó, Minas Gerais, Brasil (Amphibia, Leptodactylidae). Rev Bras Zool 2:139-146.

Christian A, Mcniel E, Robinson J, Drabek J, Larue C, Waldren C and Bedford J (1998) A versatile image analyses approach for simultaneous chromosome identification and localisation of FISH probes. Cytogenet Cell Genet 82:172-179.

Cross I, Vega L and Rebordinos L (2003) Nucleolar organizing regions in Crassostrea angulata: chromosomal location and polymorphism. Genetica 119:65-74.

De Lucchini S, Nardi I, Barsacchi G, Batistoni R and Andronico F (1993) Molecular cytogenetics of the ribosomal (18S+28S and 5S) DNA loci in primitive and advanced urodele amphibians. Genome 36:762-773.

Eickbush TH and Eickbush DG (2007) Finely orchestrated movements: evolution of the ribosomal RNA genes. Genetics 175:477-485.
Eirín-López JM, Rebordinos L, Rooney AP and Rozas J (2012) The birth-and-death evolution of multigene families revisited. Genome Dyn 7:170-196.

Eterovick PC and Sazima I (2004) Anfíbios da Serra do Cipó: Minas Gerais-Brasil. PUC Minas, Belo Horizonte.

Feio RN (2002) Revisão taxonômica do gênero Thoropa Cope, 1865 (Amphibia, Anura, Leptodactylidae). D. Sc. Thesis, Museu Nacional, Rio de Janeiro.

Feio RN, Napoli MF and Caramaschi U (2006) Considerações taxonômicas sobre Thoropa miliaris (Spix, 1824), com revalidação e redescrição de Thoropa taophora (Miranda-Ribeiro, 1923) (Amphibia, Anura, Leptodactylidae). Arq Mus Nac 64:41-60.

Fitzpatrick SW, Brasileiro CA, Haddad CFB and Zamudio KR (2009) Geographical variation in genetic structure of an Atlantic Coastal Forest frog reveals regional differences in habitat stability. Mol Ecol 18:2877-2896.

Frost DR, Grant T, Faivovich J, Bain RH, Haas A, Haddad CFB, De sá RO, Channing A, Wilkinson M, Donnellan SC et al. (2006) The amphibian tree of life. Bull Am Mus Nat Hist 297:1-291.

Garcia-Souto D, Troncoso T, Pérez M and Pasantes JJ (2015) Molecular cytogenetic analysis of the european hake Merluccius merluccius (Merlucciidae, Gadiformes): U1 and U2 snRNA gene clusters map to the same location. PloS One 10:e0146150.

Garcia S, Kovarík A, Leitch AR and Garnatje T (2017) Cytogenetic features of rRNA genes across land plants: analysis of the Plant rDNA database. Plant J 89:1020-1030.

Giaretta AA and Facure KG (2004) Reproductive ecology and behavior of Thoropa miliaris (Spix, 1824) (Anura, Leptodactylidae, Telmatobiinae). Biota Neotrop 4:1-9.

Grant T, Frost DR, Caldwell JP, Gagliardo R, Haddad CFB, Kok PJR, Means DB, Noonan BP, Schargel WE and Wheeler WC (2006) Phylogenetic systematics of dart-poison frogs and their relatives (Amphibia: Athesphatanura: Dendrobatidae). Bull Am Mus Nat Hist 299:1-262.

Guerra MS (1986) Reviewing the chromosome nomenclature of Levan et al. Rev Bras Genet 9:741-743.

Harper ME, Price J and Korn LJ (1983) Chromosomal mapping of Xenopus 5S genes: somatic-type versus oocyte-type. Nucleic Acids Res 11:2313-2323.

Howell WT and Black DA (1980) Controlled silver-staining of nucleolus organizer regions with a protective colloidal developer: a 1-step method. Cell Mol Life Sci 8:1014-1015.

King M, Contreras N and Honeycutt RL (1990) Variation within and between nucleolar organizer regions in Australian hylid frogs (Anura) shown by $18 \mathrm{~S}+28 \mathrm{~S}$ in-situ hybridization. Genetica 80:17-29.

Martins C and Galletti PM (1999) Chromosomal localization of 5S rDNA genes in Leporinus fish (Anostomidae, Characiformes). Chromosome Res 7:363-367.

Martins C and Galletti PM (2001) Two 5S rDNA arrays in Neotropical fish species: is it a general rule for fishes? Genetica 111:439-446.

Martins C, Wasko AP, Oliveira C, Porto-Foresti F, PariseMaltempi PP, Wright JM and Foresti F (2002) Dynamics of 5S rDNA in the tilapia (Oreochromis niloticus) genome: repeat units, inverted sequences, pseudogenes and chromosome loci. Cytogenet Genome Res 98:78-85.

Pendas AM, Moran P, Martinez JL and Garcia-Vazquez E (1995) Applications of 5S rDNA in Atlantic salmon, brown trout, and in Atlantic salmon brown trout hybrid identification. Mol Ecol 4:275-276. 
Pinkel Dr, Straume T and Gray JW (1986) Cytogenetic analysis using quantitative, high-sensitivity, fluorescence hybridization. Proc Natl Acad Sci U S A 83:2934-2938.

Rodrigues DS, Rivera M and Lourenço LB (2012) Molecular organization and chromosomal localization of $5 \mathrm{~S}$ rDNA in Amazonian Engystomops (Anura, Leiuperidae). BMC Genet $13: 17$

Sabbag A, Lyra ML, Zamudio KR, Haddad CF, Feio RN, Leite FS, Gasparini JL and Brasileiro CA (2018) Molecular phylogeny of Neotropical rock frogs reveals a long history of vicariant diversification in the Atlantic forest. Mol Phylogenet Evol 122:142-156.

Schmid M (1978) Chromosome banding in Amphibia I. Constitutive heterochromatin and nucleolus organizer regions in Bufo and Hyla. Chromosoma 66:361-388.

Schmid M, Steinlein C, Feichtinger W and Bogart JP (2014) Chromosome banding in Amphibia. XXXI. The Neotropical anuran families Centrolenidae and Allophrynidae. Cytogenet. Genome Res 142:268-285.

Sumner AT (1972) A simple technique for demonstrating centromeric heterochromatin. Exp Cell Res 75:304-306.

Úbeda-Manzanaro M, Merlo MA, Palazón JL, Cross I, Sarasquete $\mathrm{C}$ and Rebordinos L (2010) Chromosomal mapping of the major and minor ribosomal genes, (GATA) $n$ and U2 snRNA gene by double-colour FISH in species of the Batrachoididae family. Genetica 138:787-794.

Verdade VK, Rodrigues MT and Pavan D (2009) Anfíbios anuros da região da Estação Biológica do Alto da Serra de Paranapiacaba. In: Patrimônio da Reserva Biológica do Alto da Serra de Paranapiacaba: a antiga Estação Biológica do Alto da Serra. Instituto Botânico, São Paulo, pp 579-603.

Vitelli L, Batistoni R, Andronico F, Nardi I and Barsacchi-Pilone G (1982) Chromosomal localization of $18 \mathrm{~S}+28 \mathrm{~S}$ and $5 \mathrm{~S}$ ribosomal RNA genes in evolutionarily diverse anuran amphibians. Chromosoma 84:475-491.

Vittorazzi SE, Lourenço LB, Del-Grande ML and Recco-Pimentel SM (2011) Satellite DNA derived from 5S rDNA in Physalaemus cuvieri (Anura, Leiuperidae). Cytogenet Genome Res 134:101-107.

Wasko AP, Martins C, Wright JM and Galetti Jr PM (2001) Molecular organization of $5 \mathrm{~S}$ rDNA in fishes of the genus Brycon. Genome 44:893-902.

\section{Internet Resources}

Frost DR (2019) Amphibian Species of the World: an Online Reference, http://research.amnh.org/herpetology/amphibia/index.html (accessed 18 August 2019).

Sociedade Brasileira de Herpetologia (2018) Lista de Anfíbios, http://www.sbherpetologia.org.br/index.php/anfibios (accessed 25 June 2019).

\section{Supplementary Material}

The following online material is available for this article: Figure S1 - Telomeric probes.

Associate Editor: Marcelo Guerra

License information: This is an open-access article distributed under the terms of the Creative Commons Attribution License (type CC-BY), which permits unrestricted use, distribution and reproduction in any medium, provided the original article is properly cited. 